\title{
Premotor Parkinson's disease: Overview of clinical symptoms and current diagnostic methods
}

\author{
Michaela Kaiserova ${ }^{a}$, Zuzana Grambalova ${ }^{a}$, Sandra Kurcova ${ }^{a}$, Pavel Otruba ${ }^{a}$, Hana Prikrylova Vranova ${ }^{b}$, Katerina Mensikova ${ }^{a}$, \\ Petr Kanovsky ${ }^{a}$
}

Parkinson's disease (PD) is characterized by typical motor symptoms. However, recent studies show several non-motor features that may precede the development of the motor symptoms of PD. The best known premotor symptoms include hyposmia, REM sleep behavior disorder (RBD), constipation, and depression; other symptoms are excessive daytime somnolence, orthostatic hypotension and symptomatic hypotension, erectile or urinary dysfunction, musculoskeletal symptoms, pain, and global cognitive deficit. In this review, we summarize currently available diagnostic methods for these symptoms. We also briefly summarize neuroimaging, polyneuropathy, peripheral markers, and cerebrospinal fluid biomarkers that may be used in the early diagnosis of PD.

Key words: Parkinson's disease, premotor symptoms, diagnostic methods

Received: October 27, 2020; Revised: December 20, 2020; Accepted: January 7, 2021; Available online: February 4, 2021 https://doi.org/10.5507/bp.2021.002

(c) 2021 The Authors; https://creativecommons.org/licenses/by/4.0/

${ }^{a}$ Department of Neurology, Faculty of Medicine and Dentistry, Palacky University and University Hospital, Olomouc, Czech Republic "Neurology Outpatient Clinic "St. Moritz", Olomouc, Czech Republic

Corresponding author: Michaela Kaiserova, e-mail: michaela.kaiserova@fnol.cz

\section{INTRODUCTION}

Parkinson's disease (PD) is characterized by typical motor symptoms caused by degeneration of the substantia nigra. However, recent studies show that Lewy pathology in PD is not only present in the midbrain; it is a diffuse synucleinopathy affecting both the central and peripheral nervous system, spreading in a caudo-rostral pattern ${ }^{1,2}$. This widespread pathology results in a number of nonmotor symptoms, some of which may be present for years before the development of the typical motor symptoms of PD.

The Movement Disorders Society proposed research diagnostic criteria for prodromal PD in 2015 (ref. ${ }^{3}$ ) and updated them in 2019 (ref. ${ }^{4}$ ). These criteria comprise symptoms with a predictive value for developing PD that has been documented in prospective studies. The criteria have been validated on the general population ${ }^{5}$ REM sleep behavior disorder patients ${ }^{6}$, and LRRK2 mutation carriers ${ }^{7}$; the criteria seem to be a promising tool in identifying PD in the premotor stage ${ }^{5,8,9}$.

The best known premotor symptoms of PD include hyposmia, REM sleep behavior disorder (RBD), constipation, and depression; other non-motor features are excessive daytime somnolence, orthostatic hypotension and symptomatic hypotension, erectile or urinary dysfunction, and global cognitive deficit. Pain, sometimes accompanied by musculoskeletal symptoms, may also occur in the premotor phase of PD.

The aim of this review is to summarize the currently available methods for diagnosing the premotor symptoms of PD which may help in the early diagnosis of PD.

\section{Olfactory functions}

Olfactory impairment is common in PD; its prevalence is estimated to be $50-90 \%\left(\right.$ ref. $^{10}$ ). Olfactory impairment often precedes motor symptoms by years; idiopathic olfactory loss is considered a risk factor for PD (ref. ${ }^{11-13}$ ).

Questionnaires may be used as a screening instrument for olfactory dysfunction. Questions concerning olfactory functions are usually part of more complex questionnaires, such as the Non-Motor Symptoms Questionnaire (NMSQest) $\left(\right.$ ref. $\left.{ }^{14}\right)$, the International Parkinson and Movement Disorder Society - Non-Motor Rating Scale (MDS-NMS) (ref. ${ }^{15}$ ), and the Non-Motor Symptoms Scale for Parkinson's Disease (NMSS) ( ref. $^{16}$ ).

Many PD patients are unaware of their impairment and overestimate their ability to smell, which makes selfreport questionnaires unreliable ${ }^{17,18}$. For this reason, a gold standard in daily practice are psychophysical tests ${ }^{19}$. These tests are based on the presentation of different odors to the subject. The test that was first developed and is still widely used due to its easy administration is the University of Pennsylvania Smell Identification Test (UPSIT). This test, developed in the United States, provides 40 odors; the subject is supposed to identify the odor by choosing the best result from the offered selection $^{20}$. Cultural and social factors may be a limitation of this test, as some odors are not familiar in some countries. This possibility has led to several local adaptations of the test $^{21-25}$. One shorter version of UPSIT is the National Health and Nutrition Examination Survey (NHANES) eight-item odor identification test (Pocket Smell Test ${ }^{\mathrm{TM}}$ ) $\left(\right.$ ref. $\left.{ }^{26}\right)$. There is a twelve-item test, called the Brief Smell Identification Test (B-SIT) and also known as the CrossCultural Smell Identification Test (CC-SIT) $\left(\right.$ ref. $^{27}$ ). 
Another test, more popular in Europe, is the Sniffin' Sticks test. This test is able to test all three olfactory qualities: odor-identification, odor-discrimination, and olfactory threshold ${ }^{28}$. To find the olfactory threshold, 16 trios of sticks are used. In each trio, one stick is impregnated with n-butanol or 2-phenylethanol diluted in a solvent in a different concentration. The subject is supposed to identify this stick from among the other sticks containing only the solvent. For the odor-discrimination testing, 16 trios of sticks are also used. In each trio, two sticks are impregnated with the same odor and the third one is impregnated with a different odor. The subject is then required to identify the stick with the different odor. The last part of the test is focused on odor identification. Sixteen odors are given and the subject must choose one from four suggestions $^{28,29}$. The disadvantage of this validated test is that it is time consuming. However, some studies show that the odor-identification subtest may be equal to the whole test battery ${ }^{30-32}$.

The Snap and Sniff ${ }^{\circledR}$ Threshold test (S\&S-T) was recently developed for detecting olfactory thresholds. This test uses 20 smell wands; five contain no odorant, the others contain diluted 2-phenylethanol in increasing concentrations ${ }^{33}$.

There are other smell tests, such as SMELL-S and SMELL-R that test olfactory sensitivity and olfactory resolution ${ }^{34}$, fast Q-Sticks test presenting three odors in felt-tip pens ${ }^{35}$, the Connecticut Chemosensory Clinical Research Center (CCCRC) identification test measuring odor-identification and threshold ${ }^{36}$, the Smell Diskettes Test using eight different odors with a high degree of familiarity in Central Europe ${ }^{37}$, the Barcelona Smell Test-24 (BAST-24) with 24 odors $^{38}$, a 4 min odor identification test with 12 odors in sticks ${ }^{39}$, the European Test of Olfactory Capabilities (ETOC) testing odor-identification and threshold, validated in three European countries ${ }^{40}$, the three-item Q-SIT ( ref. $^{41}$ ), the Odor Stick Identification Test using 13 odors in microcapsules incorporated into a stable cream and encased like a lipstick ${ }^{42}$, and the 16-item Scandinavian Odor Identification Test ${ }^{43}$.

Psychophysical tests are non-invasive and easily available, and many are inexpensive and not time consuming, so they may be used to diagnose olfactory dysfunction in $\mathrm{PD}$, even in the premotor phase. The limitation is that despite the high sensitivity for predicting PD, the specificity is low, because up to one in three elderly people have olfactory loss of various other etiologies ${ }^{44}$. Therefore, smell tests alone are not sufficient to diagnose PD in the premotor phase. Additional tests of other premotor symptoms must be conducted.

An objective method to test olfactory function is electrophysiologic recording. In PD patients, olfactory eventevoked potentials (OERP) returned abnormal results ${ }^{45,46}$. Electrophysiologic recordings are rarely used in clinical practice because of the complexity to perform them and economic aspects ${ }^{47}$.

The sniff magnitude test may be an alternative to psychophysical tests in PD. This test is based on the reflexlike response to malodors by quantifying the decrease of inhalation when a malodorous stimulus is encountered ${ }^{48,49}$.
This test seem to be less sensitive than other measures ${ }^{50,51}$, and does not give information on clinically relevant olfactory functions such as odor identification, differentiation, and threshold ${ }^{52}$. It may nevertheless be a good alternative for investigating PD patients with dementia.

As mentioned above, current olfactory tests have low specificity for diagnosing premotor PD. To become more specific, recent PD studies have focused on other methods, such as biopsy of olfactory epithelium, measuring the olfactory bulb volume, and functional neuroimaging.

Olfactory bulb and olfactory mucosa biopsies are based on the recent finding that $\alpha$-synuclein can be detected in peripheral tissues such as the gastrointestinal tract, salivary glands, skin, retina, heart, adrenal gland, and olfactory tissue ${ }^{53,54}$. Positive $\alpha$-synuclein staining of olfactory bulb specimens ranged from $8 \%$ to $100 \%$ for PD compared to $2-100 \%$ in a control group ${ }^{53,54}$. This examination is invasive and not without risk and all studies published thus far were restricted to postmortem investigations. In vivo tests have been restricted to the olfactory mucosa. Witt et al. found no specific changes in the nasal mucosa of PD compared to patients who were hyposmic for other reasons; moreover, $\alpha$-synuclein was also observed in normosmic controls ${ }^{55}$.

Olfactory bulb volume is possible to measure using a 1.5 Tesla MRI (ref. ${ }^{56}$ ). Several studies showed a correlation between olfactory bulb volume and olfactory function $^{57-59}$. In PD, however, the results are not convincing. Some studies showed reduced olfactory bulb volume on both sides ${ }^{60-62}$; other studies did not find any difference between PD patients and healthy controls ${ }^{63,64}$. Hakyemez et al. even found increased olfactory bulb volume in Hoehn \&Yahr stage 1 and $2\left(\right.$ ref $^{65}{ }^{65}$. These different results indicate that additional studies will be needed to see whether the measurement of olfactory bulb volume may become a useful and reliable method for diagnosis of premotor PD.

\section{Autonomic dysfunction}

Autonomic dysfunction is present in early PD; some symptoms may precede the motor symptoms of the disease by many years ${ }^{66-68}$.

The most reliable autonomic premotor symptom is constipation; other symptoms are erectile and urinary dysfunction and orthostatic hypotension or symptomatic hypotension ${ }^{69-75}$.

\section{Constipation}

The Movement Disorder Society (MDS) Task Force on Rating Scales for PD evaluated scales for gastrointestinal-related autonomic symptoms in PD that were used previously as outcome measures in studies with PD patients $^{76}$. Scales were rated as recommended if they were valid, reliable, and sensitive and had been used in clinical studies beyond the group that developed it. There was no recommended scale for constipation. The Rome III Criteria may be used to define constipation; however, this scale has not been validated for the PD population.

Global scales addressing dysautonomia and nonmotor symptoms, including constipation, are used more often. 
The Scales for Outcomes in PD-Autonomic (SCOPAAUT) (ref. ${ }^{77}$ ) and the Nonmotor Symptoms Questionnaire for PD (NMSQuest) (ref. ${ }^{14}$ ) were recommended. The Nonmotor Symptoms Scale (NMSS) (ref. ${ }^{16}$ ) was also suggested.

Apart from questionnaires, laboratory tests may also detect gastrointestinal dysfunction. PD patients have prolonged colonic transit time (CCT) (ref. ${ }^{78,79}$ ); abnormal results may be present also in patients with no subjective constipation symptoms ${ }^{80,81}$. The most commonly used technique is measuring CCT using radio-opaque markers. A defined number of these markers is ingested, an abdominal $\mathrm{x}$-ray is performed $24 \mathrm{~h}$ after the ingestion of the last capsule, and the estimated transit time is measured from the number of retained markers ${ }^{82,83}$. This simple method may have some potential in diagnosing prodromal PD; however, there are still no studies using this method in premotor PD.

Constipation in PD is probably caused not only by delayed CCT, but also by anorectal dysfunction, which can be measured by anorectal manometry or by defecography ${ }^{81,84}$. Published studies are mostly based on small patient samples and variable methodology ${ }^{84}$ so the possible use of these methods in diagnosing prodromal PD have to be established on future larger studies.

\section{Erectile dysfunction}

PD is associated with increased risk of sexual dysfunction and this dysfunction may be present in the preclinical stage of PD (ref. ${ }^{85}$ ). Problems with sexual dysfunction are reported especially by $\operatorname{men}^{85,86}$. Studies dealing with sexual dysfunction in women have produced controversial results $^{86,87}$. Erectile dysfunction has been found to be a risk factor of $\mathrm{PD}$ (ref. ${ }^{71,75}$ ) but the prevalence of erectile dysfunction in the non-parkinsonian population is also significant ${ }^{88,89}$ so this symptom must be evaluated carefully in context with other premotor symptoms. Questionnaires are currently preferred in diagnosing erectile dysfunction. One widely used questionnaire is the International Index of Erectile Function (IIEF) (ref. ${ }^{90-92}$ ). Another questionnaire concerning sexual dysfunction that has been used in PD studies is the Arizona Sexual Experience Scale (ASEX), an easily applicable five-item questionnaire ${ }^{93,94}$. The Female Sexual Function Index (FSFI) is focused on women $^{95}$. Questions concerning sexual function are also a part of global scales addressing dysautonomia in PD - SCOPA-AUT ( ref. $^{77}$ ), NMSQuest (ref. ${ }^{14}$ ), and NMSS (ref. $\left.{ }^{16}\right)$.

\section{Urinary dysfunction}

Up to $71 \%$ of PD patients report lower urinary tract symptoms. Patients most commonly complain about storage symptoms, such as nocturia, urgency, and daytime frequency; up to $26 \%$ of men and $28 \%$ of women with PD experience urinary incontinence ${ }^{96}$. Voiding symptoms are less common, but may also occur in PD; patients have higher rates of difficulty initiating urination, poor stream, straining ${ }^{97}$. Questionnaires are a useful instrument for detecting urinary dysfunction in PD. There are global dysautonomia scales comprising urinary symptoms; these scales are mentioned above. Scales focused on urinary dysfunction that were used in the PD population are the American Urological Association Symptom Index (AUA-SI) (ref. ${ }^{98}$ ) and the International Prostate Symptom Score (I-PSS) (ref. ${ }^{99}$ ) for men and the short form of the Urogenital Distress Inventory (UDI-6) (ref. ${ }^{100}$ ) for women. Another questionnaire used in PD is the Overactive Bladder Questionnaire (OAB-q) (ref. ${ }^{101,102}$ ). This questionnaire has 36 items but there is also a short eight-item form.

Urodynamic studies use objective methods that assess the lower urinary tract function. In one study, urodynamic tests revealed abnormal findings in $82 \%$ of early and untreated PD patients; this was more than the questionnairebased subjective symptoms of urinary dysfunction (64\%) (ref. ${ }^{103}$ ). These findings suggest that urinary dysfunction in the early stages of PD may be asymptomatic or have little influence on quality of life, so the symptoms may be overlooked ${ }^{103}$.

\section{Orthostatic hypotension and symptomatic hypotension}

Orthostatic hypotension $(\mathrm{OH})$ is defined as a sustained reduction of systolic blood pressure of at least 20 $\mathrm{mmHg}$ or diastolic blood pressure of $10 \mathrm{~mm} \mathrm{Hg}$ within 3 min of standing or a head-up tilt to at least $60^{\circ}$ on a tilt table ${ }^{104}$. It has been shown that $\mathrm{OH}$ may precede the motor symptoms of PD (ref. ${ }^{68,75,105,106}$ ). OH may be symptomatic or asymptomatic and the symptoms may vary across patients from lightheadedness, to dizziness, to pre-syncope and syncope. Some patients report weakness, fatigue, cognitive slowing, leg buckling, visual blurring, neck pain, headache, and orthostatic dyspnea of chest pain ${ }^{104}$.

The MDS analyzed the scales and questionnaires for $\mathrm{OH}$ that were used in PD (ref. ${ }^{107}$ ). Most of them were larger scales or questionnaires globally assessing nonmotor and autonomic functions. Some scales detect $\mathrm{OH}$-related symptoms and provide information on the severity and/ or frequency. From these scales, the ones recommended with limitations were SCOPA - AUT (ref. ${ }^{77}$ ) and the Composite Autonomic Symptom Scale (COMPASS) with the orthostatic subsection ${ }^{108}$. The Non-Motor Symptoms Scale for Parkinson's Disease (NMSS) (ref. ${ }^{16}$ ) was categorized as suggested because its use has not been reported outside the validation study that later changed ${ }^{109,110}$. The Orthostatic Grading Scale (OGS), a five-item questionnaire focused only on $\mathrm{OH}$ (ref. ${ }^{111}$ ) was also suggested because it needed to be validated on a PD population. Later the scale was validated on a group in Korea ${ }^{112}$.

There are scales that may be used as screening tools for $\mathrm{OH}$ but do not score the severity/frequency of orthostatic symptoms. The strongest clinimetric testing has been performed on the NMS Quest (ref. ${ }^{14}$ ).

An easily performed objective test for $\mathrm{OH}$ is a measurement of blood pressure after at least $5 \mathrm{~min}$ in a supine position and then after 1 and $3 \mathrm{~min}$ of standing ${ }^{113}$. The passive head-up tilt test (HUT) is recommended if the active standing test is negative and the patient history is suggestive of $\mathrm{OH}$, and in patients with severe motor impairment where it is not possible to perform an active orthostatic test ${ }^{114}$. In cases where the supine-to-standing 
test of HUT is difficult to perform, a seated-to-standing orthostatic test may be an alternative ${ }^{115,116}$.

\section{REM sleep behavior disorder (RBD) and excessive daytime somnolence}

$\mathrm{RBD}$ is considered to be one of the strongest clinical markers of prodromal neurodegenerative synucleinopathy ${ }^{6,117-119}$. A definite diagnosis of RBD is determined according to the International Classification of Sleep Disorders-3 (ICSD-3) (ref. ${ }^{120}$ ), where polysomnography (PSG) plays an essential role. PSG remains the gold standard for diagnosis of RBD. However, questionnaires are still useful in clinical practice. Several screening questionnaires were developed for screening of RBD. A commonly used questionnaire is the 10-item RBD screening questionnaire (RBDSQ), validated on PD populations ${ }^{121-125}$. Another questionnaire focused solely on RBD is the Sleep Behavior Disorder Single Question Screen (RBD1Q) (ref. $\left.{ }^{126}\right)$.

Based on two studies, excessive daytime somnolence is considered a premotor feature of PD (ref. ${ }^{127,128}$ ). To assess daytime sleepiness, the Epworth sleepiness scale (ESS) was developed ${ }^{129}$ and has been used in PD populations ${ }^{130-132}$.

There are questionnaires used in PD that cover both nocturnal sleep disorders (including RBD) and excessive daytime sleepiness ${ }^{133}$. The Parkinson's Disease Sleep Scale (PDSS) (ref. ${ }^{134}$ ), the revised version PDSS-2 (ref. ${ }^{135}$ ), and the Scales for Outcomes in PD-Sleep (SCOPA-Sleep) (ref. ${ }^{136}$ ) were designed and validated for PD populations. Questions on sleep disturbances including excessive daytime somnolence are included in general nonmotor questionnaires - NMSQuest (ref. ${ }^{14}$ ), NMSS (ref. ${ }^{16}$ ), and MDS-UPDRS Part I (ref. ${ }^{137}$ ).

\section{Depression}

Several studies have shown that depression increases the risk of PD (ref. ${ }^{75,138-141}$ ), but its sensitivity and specificity is $l o w^{44}$. Depression rating scales used in PD studies were analyzed with estimations of the sensitivity and specificity of each test in PD populations ${ }^{142,143}$. Scales suitable for screening purposes are the 30-item and 15-item Geriatric Depression Scale (GDS-30, GDS-15) (ref. ${ }^{144,145}$ ), the Beck Depression Inventory (BDI) (ref. ${ }^{146}$ ), The Montgomery Åsberg Depression Rating Scale (MADRS) (ref. ${ }^{147}$ ), the Hamilton Rating Scale for Depression (HAMD-17) (ref. ${ }^{148}$ ), and the Hospital Anxiety and Depression Scale (HADS) (ref. $\left.{ }^{149}\right)$. A crude screening instrument for depression is also the MDS-UPDRS Part I (ref. ${ }^{137}$ ). To measure the severity of depression, HAMD-17, MADRS, BDI, or the Zung Self-Rating Depression Scale (SDS) (ref. ${ }^{150}$ ) may be used.

\section{Cognitive deficit}

Cognitive deficit was recently added to the prodromal symptom spectrum of PD (ref. ${ }^{4}$ ) on the basis of the results of three studies ${ }^{151-153}$. The most frequent cognitive deficit is executive dysfunction, the second most frequent is memory; there can also be deficits in attention and visuospatial functions; and global cognitive impairment has also been described ${ }^{154}$. Detailed neuropsychological testing is a gold standard to assess the most commonly affected cognitive domains. This testing, however, is time consuming and not available in all settings. Therefore, global cognitive tests covering the most relevant cognitive domains were evaluated $^{155}$. Three scales were recommended without caveats: the Mattis Dementia Rating Scale Second Edition (DRS-2) (ref. ${ }^{156}$ ), which takes about 20 -30 min to administer and is divided into 5 subscales: Attention, Initiation/ Perseveration, Construction, Conceptualization, and Memory. Another recommended scale was the Montreal Cognitive Assessment (MoCA) (ref. ${ }^{157}$ ), taking about 10 min to administer and assessing memory, visuospatial skills, attention and concentration, executive functions, language, conceptual thinking, calculations, and orientation. The last recommended test was the Parkinson's Disease-Cognitive Rating Scale (PD-CRS) (ref. ${ }^{158}$ ), taking about 20 min to administer and covering both cortical functions, such as naming and copy drawing of a clock, and subcortical functions, including attention, working memory, verbal memory, visuoconstruction, alternating, and action fluency. The widely used 30-point Mini-Mental State Examination (MMSE) (ref. ${ }^{159}$ ) was rated only as suggested for PD patients, as other cognitive scales have shown better capacity and sensitivity for detecting dementia in PD, and because MMSE does not adequately assess executive and visuospatial functions, which are characteristically affected in PD and is also not sensitive to detecting early stages of cognitive deterioration.

\section{Pain}

Pain occurs early in the disease course, even as a premotor symptom of PD (ref. ${ }^{160-163}$ ). The MDS evaluated available ratings scales for pain that may be used in PD (ref. $\left.{ }^{164}\right)$. The only recommended scale for pain intensity rating was the King's PD Pain Scale ${ }^{165}$. This scale encompasses seven pain domains seen in PD: musculoskeletal, chronic, fluctuation-related, nocturnal, orofacial, discoloration/swelling, and radicular pain. When assessing scales in terms of pain syndromic classification, the MDS evaluated the King's PD Pain Scale as only suggested because it has not been adequately validated. The Douleur Neuropathique 4 (DN4) was recommended with caution due to lack of clinimetric data in PD (ref. ${ }^{166}$ ).

\section{Small fiber neuropathy}

Both large and small fiber neuropathy may be associated with PD (ref. ${ }^{167-169}$ ). There are reports that PD may be associated also with motor neuron disease ${ }^{170,171}$. A recent study suggested that small fiber pathology may precede the development of motor symptoms of PD (ref. ${ }^{172}$ ). Small fiber functions may be investigated bedside by responsiveness to heat, cold, and pain evoked by pinprick. There are also several specific neurophysiological and pathological techniques for detecting small fiber pathology, such as skin biopsy, quantitative sensory testing, quantitative sudomotor axon reflex test, corneal confocal microscopy, microneurography, and electrical and laser evoked potentials ${ }^{173}$. 


\section{Neuroimaging}

Except for clinical features, several neuroimaging methods can help with the diagnosis of premotor PD. The wide range of imaging modalities can be divided into three groups ${ }^{174}$ : targeting dopaminergic function in the basal ganglia using radio-labelled ligands, detected by single photon emission computed tomography (SPECT) or positron emission tomography (PET) (ref. ${ }^{175,176}$ ); direct imaging of the substantia nigra by transcranial sonography detecting increased echogenicity of substantia nigra ${ }^{177,178}$ or brain MRI focusing on brainstem structures ${ }^{179-181}$; and imaging brain network activity with measuring metabolic activity, changes in blood oxygenation of regional cerebral blood flow ${ }^{174,182,183}$.

\section{Peripheral markers}

${ }^{123}$ I-metaiodobenzylguanidine (MIBG) uptake is decreased in PD, indicating myocardial postganglionic sympathetic denervation ${ }^{184}$ and seems to be promising in the diagnosis of premotor PD (ref. ${ }^{185,186}$ ).

Detection of phosphorylated $\alpha$-synuclein in skin biopsies seems to be a sensitive and specific marker of PD and also of premotor PD (ref.4,187,188). Submandibular glands ${ }^{187,189}$ and gastrointestinal tract mucosa are also tested for $\alpha$-synuclein in premotor PD (ref. ${ }^{187}$ ). In one study, $\alpha$-synuclein was found in the enteric mucosa in the same manner in the PD patients and the controls ${ }^{190}$.

\section{Cerebrospinal fluid}

Studies usually focus on biomarker candidates for distinguishing between PD and controls or on differentiating PD from other neurodegenerative disorders. The biomarkers may be divided into six categories ${ }^{191,192}$. A: Neurotransmitters and neuromodulators; Goldstein et al. found low CSF DOPA and/or low CSF 3,4-dihydroxyphenylacetic acid (DOPAC), the main neuronal metabolite of dopamine, in people with multiple risk factors for PD who subsequently developed clinical features of PD (ref. ${ }^{193}$ ). B: Oxidative stress markers; mutations in DJ-1 gene/PARK7 are associated with PD; however, the results of the studies measuring CSF DJ-1 levels are not yet conclusive ${ }^{191}$. C: Inflammatory and immunological markers; several cytokines were found to be increased in PD, such as $\beta 2$-microglobulin and IL-8 (ref. ${ }^{194}$ ), IL-6 and IL-1-B were increased in cognitively impaired PD (ref. ${ }^{195}$ ). D: Growth factors; in one study, brain-derived neurotrophic factor (BDNF) was found to be increased in PD patients ${ }^{194}$. E: Proteins involved in PD pathology; a commonly studied biomarker is $\alpha$ - synuclein. This protein has a tendency to be lower in PD; however, not all published studies have consistent results ${ }^{196-198}$. Studies with CSF total tau, phosphorylated tau, and amyloid- $\beta$ protein and its variants also had inconclusive results ${ }^{191,194,199-201}$. Neurofilament light chain (NfL) seems to be useful in differential diagnosis of PD and atypical parkinsonism ${ }^{200,202}$. Clustering was found to be increased in PD (ref. ${ }^{199,203-205}$ ). One study found decreased YKL-40 in PD patients compared to controls ${ }^{206}$. F: Other. Although many studies try to establish potential CSF biomarkers of PD, the application of CSF examination in the diagnosis of premotor
PD is still limited. Only a few studies have focused on the premotor stages of PD; sampling techniques and analysis procedures differ across the studies, and the results are often conflicting. Larger longitudinal studies will be necessary to establish CSF biomarkers of premotor PD.

In conclusion, recent studies show that there are several non-motor symptoms with predictive value for the development of PD. They are currently being tested in research settings due to the lack of effective neuroprotective therapy. However, as soon as an adequate treatment is available, it will be a priority for clinicians to establish the diagnosis of PD in the early/premotor stages in order to preserve the patients' quality of life.

\section{Search strategy and selection criteria}

We searched PubMed, Web of science and Google scholar using the keywords Parkinson's disease, premotor symptoms, olfactory functions, autonomic dysfunction, constipation, erectile dysfunction, urinary dysfunction, orthostatic hypotension, REM sleep behavior disorder, depression, cognitive functions, pain, small fibre neuropathy, neuroimaging, cerebrospinal fluid.

Acknowledgement: This study was supported by a grant from the Ministry of Health of the Czech Republic - AZV NV18-04-00346; by the European Regional Development Fund - Project ENOCH (No. Z.02.1.01/0.0/0.0/16_019/0 000868); and by the Ministry of Health, Czech Republic Institutional Support 2020 - conceptual development of a research organization (FNO1, 0098892).

Author contributions: MK: manuscript writing, literature search; ZG, SK, PO, HPV, KM: manuscript revision; PK: critical reading, final approval.

Conflict of interest statement: The authors declare that they have no conflicts of interest.

\section{REFERENCES}

1. Del Tredici K, Braak H. Lewy pathology and neurodegeneration in premotor Parkinson's disease. Mov Disord 2012;27(5):597-607.

2. Braak H, Ghebremedhin E, Rub U, Bratzke H, Del Tredici K. Stages in the development of Parkinson's disease-related pathology. Cell Tissue Res 2004;318(1):121-34.

3. Berg D, Postuma RB, Adler CH, Bloem BR, Chan P, Dubois B, Gasser T, Goetz CG, Halliday G, Joseph L, Lang AE, Liepelt-Scarfone I, Litvan I, Marek K, Obeso J, Oertel W, Olanow CW, Poewe W, Stern M, Deuschl G. MDS research criteria for prodromal Parkinson's disease. Mov Disord 2015;30(12):1600-11.

4. Heinzel S, Berg D, Gasser T, Chen H, Yao C, Postuma RB, Disease MDSTFotDoPs. Update of the MDS research criteria for prodromal Parkinson's disease. Mov Disord 2019;34(10):1464-70.

5. Mahlknecht P, Gasperi A, Willeit P, Kiechl S, Stockner H, Willeit J, Rungger G, Sawires M, Nocker M, Rastner V, Mair KJ, Hotter A, Poewe W, Seppi K. Prodromal Parkinson's disease as defined per MDS research criteria in the general elderly community. Mov Disord 2016;31(9):1405-8.

6. Fereshtehnejad SM, Montplaisir JY, Pelletier A, Gagnon JF, Berg D, Postuma RB. Validation of the MDS Research Criteria for Prodromal Parkinson's Disease: Longitudinal Assessment in a REM Sleep Behavior Disorder (RBD) Cohort. Mov Disord 2017;32(6):865-73.

7. Mirelman A, Saunders-Pullman R, Alcalay RN, Shustak S, Thaler A, Gurevich T, Raymond D, Mejia-Santana H, Orbe Reilly M, Ozelius L, Clark L, Gana-Weisz M, Bar-Shira A, Orr-Utreger A, Bressman SB, Marder K, Giladi N, Consortium AL. Application of the Movement 
Disorder Society prodromal criteria in healthy G2019S-LRRK2 carriers. Mov Disord 2018;33(6):966-73.

8. Pilotto A, Heinzel S, Suenkel U, Lerche S, Brockmann K, Roeben B, Schaeffer E, Wurster I, Yilmaz R, Liepelt-Scarfone I, von Thaler AK, Metzger FG, Eschweiler GW, Postuma RB, Maetzler W, Berg D. Application of the Movement Disorder Society Prodromal Parkinson's Disease Research Criteria in 2 Independent Prospective Cohorts. Mov Disord 2017;32(7):1025-34.

9. Fereshtehnejad SM, Montplaisir JY, Pelletier A, Gagnon JF, Berg D, Postuma RB. Validation of the MDS research criteria for prodromal Parkinson's disease: Longitudinal assessment in a REM sleep behavior disorder (RBD) cohort. Mov Disord 2017;32(6):865-73.

10. Fullard ME, Morley JF, Duda JE. Olfactory Dysfunction as an Early Biomarker in Parkinson's Disease. Neurosci Bull 2017;33(5):515-25.

11. Haehner A, Hummel T, Hummel C, Sommer U, Junghanns $S$, Reichmann H. Olfactory loss may be a first sign of idiopathic Parkinson's disease. Mov Disord 2007;22(6):839-42.

12. Ponsen MM, Stoffers D, Booij J, van Eck-Smit BL, Wolters E, Berendse HW. Idiopathic hyposmia as a preclinical sign of Parkinson's disease. Ann Neurol 2004;56(2):173-81.

13. Ross GW, Petrovitch H, Abbott RD, Tanner CM, Popper J, Masaki K Launer L, White LR. Association of olfactory dysfunction with risk for future Parkinson's disease. Ann Neurol 2008;63(2):167-73.

14. Chaudhuri KR, Martinez-Martin P, Schapira AH, Stocchi F, Sethi $K$, Odin P, Brown RG, Koller W, Barone P, MacPhee G, Kelly L, Rabey M, MacMahon D, Thomas S, Ondo W, Rye D, Forbes A, Tluk S, Dhawan V, Bowron A, Williams AJ, Olanow CW. International multicenter pilot study of the first comprehensive self-completed nonmotor symptoms questionnaire for Parkinson's disease: the NMSQuest study. Mov Disord 2006;21(7):916-23.

15. Chaudhuri KR, Schrag A, Weintraub D, Rizos A, Rodriguez-Blazquez C, Mamikonyan E, Martinez-Martin P. The Movement Disorder Society Nonmotor Rating Scale: Initial Validation Study. Mov Disord 2020;35(1):116-33.

16. Chaudhuri KR, Martinez-Martin P, Brown RG, Sethi K, Stocchi F, Odin P, Ondo W, Abe K, Macphee G, Macmahon D, Barone P, Rabey M, Forbes A, Breen K, Tluk S, Naidu Y, Olanow W, Williams AJ, Thomas $S$, Rye D, Tsuboi Y, Hand A, Schapira AH. The metric properties of a novel non-motor symptoms scale for Parkinson's disease: Results from an international pilot study. Mov Disord 2007;22(13):1901-11.

17. Leonhardt B, Tahmasebi R, Jagsch R, Pirker W, Lehrner J. Awareness of olfactory dysfunction in Parkinson's disease. Neuropsychology 2019;33(5):633-41.

18. White TL, Sadikot AF, Djordjevic J. Metacognitive knowledge of olfactory dysfunction in Parkinson's disease. Brain Cogn 2016;104:1-6.

19. Doty RL. Psychophysical testing of smell and taste function. Handb Clin Neurol 2019;164:229-46.

20. Doty RL, Shaman P, Kimmelman CP, Dann MS. University of Pennsylvania Smell Identification Test - a Rapid Quantitative Olfactory Function-Test for the Clinic. Laryngoscope 1984;94(2):1768.

21. Taherkhani S, Moztarzadeh F, Seraj JM, Nazari SSH, Taherkhani F, Gharehdaghi J, Okazi A, Pouraghaei S. Iran Smell Identification Test (Iran-SIT): a Modified Version of the University of Pennsylvania Smel Identification Test (UPSIT) for Iranian Population. Chem Percept 2015;8(4):183-91.

22. Ogihara H, Kobayashi M, Nishida K, Kitano M, Takeuchi K. Applicability of the cross-culturally modified University of Pennsylvania Smel Identification Test in a Japanese population. Am J Rhinol Allergy 2011;25(6):404-10.

23. Fornazieri MA, dos Santos CA, Bezerra TF, Pinna Fde R, Voegels RL, Doty RL. Development of normative data for the Brazilian adaptation of the University of Pennsylvania Smell Identification Test. Chem Senses 2015;40(2):141-9.

24. Hsu NI, Lai JT, Shen PH. Development of Taiwan Smell Identification Test: a quick office-based smell screening test for Taiwanese. Am $J$ Rhinol Allergy 2015;29(2):e50-4.

25. Picillo $M$, lavarone $A$, Pellecchia $M T$, Amboni $M$, Erro R, Moccia $M$, Vitale C, Longo K, Santangelo G, Spina E, Scannapieco S, Orefice G, Barone P. Validation of an Italian version of the 40-item University of Pennsylvania Smell Identification Test that is physician administered our experience on one hundred and thirty-eight healthy subjects. Clin Otolaryngol 2014;39(1):53-7.

26. Rawal S, Hoffman HJ, Honda M, Huedo-Medin TB, Duffy VB. The Taste and Smell Protocol in the 2011-2014 US National Health and
Nutrition Examination Survey (NHANES): Test-Retest Reliability and Validity Testing. Chem Percept 2015;8(3):138-48.

27. Doty RL, Marcus A, Lee WW. Development of the 12-item CrossCultural Smell Identification Test (CC-SIT). Laryngoscope 1996;106(3 Pt 1):353-6.

28. Hummel T, Sekinger B, Wolf SR, Pauli E, Kobal G. 'Sniffin' sticks': olfactory performance assessed by the combined testing of odor identification, odor discrimination and olfactory threshold. Chem Senses 1997;22(1):39-52.

29. Rumeau C, Nguyen DT, Jankowski R. How to assess olfactory performance with the Sniffin' Sticks test (R). Eur Ann Otorhinolaryngol Head Neck Dis 2016;133(3):203-6.

30. Krismer F, Pinter B, Mueller C, Mahlknecht P, Nocker M, Reiter E, Djamshidian-Tehrani A, Boesch SM, Wenning GK, Scherfler C, Poewe W, Seppi K. Sniffing the diagnosis: Olfactory testing in neurodegenerative parkinsonism. Parkinsonism Relat Disord 2017;35:36-41.

31. Daum RF, Sekinger B, Kobal G, Lang CJ. [Olfactory testing with "sniffin' sticks" for clinical diagnosis of Parkinson disease]. Nervenarzt 2000;71(8):643-50.

32. Mesholam RI, Moberg PJ, Mahr RN, Doty RL. Olfaction in neurodegenerative disease: a meta-analysis of olfactory functioning in Alzheimer's and Parkinson's diseases. Arch Neurol 1998;55(1):84-90.

33. Doty RL, Wylie C, Potter M, Beston R, Cope B, Majam K. Clinical validation of the olfactory detection threshold module of the Snap \& Sniff(R) olfactory test system. Int Forum Allergy Rhinol 2019;9(9):98692.

34. Hsieh JW, Keller A, Wong M, Jiang RS, Vosshall LB. SMELL-S and SMELL-R: Olfactory tests not influenced by odor-specific insensitivity or prior olfactory experience. Proc Natl Acad Sci U S A 2017;114(43):11275-84

35. Sorokowska A, Oleszkiewicz A, Minovi A, Konnerth CG, Hummel T. Fast Screening of Olfactory Function Using the Q-Sticks Test. ORL J Otorhinolaryngol Relat Spec 2019;81(5-6):245-51.

36. Cain WS, Gent JF, Goodspeed RB, Leonard G. Evaluation of olfactory dysfunction in the Connecticut Chemosensory Clinical Research Center. Laryngoscope 1988;98(1):83-8.

37. Briner HR, Simmen D. Smell diskettes as screening test of olfaction. Rhinology 1999;37(4):145-8.

38. Cardesin A, Alobid I, Benitez P, Sierra E, de Haro J, Bernal-Sprekelsen M, Picado C, Mullol J. Barcelona Smell Test - 24 (BAST-24): validation and smell characteristics in the healthy Spanish population. Rhinology 2006;44(1):83-9.

39. Hummel T, Konnerth CG, Rosenheim K, Kobal G. Screening of olfactory function with a four-minute odor identification test: reliability, normative data, and investigations in patients with olfactory loss. Ann Otol Rhinol Laryngol 2001;110(10):976-81.

40. Thomas-Danguin $T$, Rouby $C$, Sicard G, Vigouroux $M$, Farget $V$ Johanson A, Bengtzon A, Hall G, Ormel W, De Graaf C, Rousseau F, Dumont JP. Development of the ETOC: a European test of olfactory capabilities. Rhinology 2003;41(3):142-51.

41. Jackman AH, Doty RL. Utility of a three-item smell identification test in detecting olfactory dysfunction. Laryngoscope 2005;115(12):2209-12.

42. Saito S, Ayabe-Kanamura S, Takashima Y, Gotow N, Naito N, Nozawa T, Mise M, Deguchi Y, Kobayakawa T. Development of a smell identification test using a novel stick-type odor presentation kit. Chem Senses 2006;31(4):379-91.

43. Nordin S, Bramerson A, Liden E, Bende M. The Scandinavian OdorIdentification Test: development, reliability, validity and normative data. Acta Otolaryngol 1998;118(2):226-34.

44. Postuma RB, Aarsland D, Barone P, Burn DJ, Hawkes CH, Oertel W, Ziemssen T. Identifying prodromal Parkinson's disease: pre-motor disorders in Parkinson's disease. Mov Disord 2012;27(5):617-26.

45. Barz S, Hummel T, Pauli E, Majer M, Lang CJ, Kobal G. Chemosensory event-related potentials in response to trigeminal and olfactory stimulation in idiopathic Parkinson's disease. Neurology 1997:49(5):1424-31.

46. Sakuma K, Nakashima K, Takahashi K. Olfactory evoked potentials in Parkinson's disease, Alzheimer's disease and anosmic patients. Psychiatry Clin Neurosci 1996;50(1):35-40.

47. Nguyen DT, Rumeau C, Gallet P, Jankowski R. Olfactory exploration: State of the art. Eur Ann Otorhinolaryngol Head Neck Dis 2016;133(2):113-8.

48. Frank RA, Dulay MF, Gesteland RC. Assessment of the Sniff 
Magnitude Test as a clinical test of olfactory function. Physiol Behav 2003;78(2):195-204.

49. Xiao Q, Chen S, Le W. Hyposmia: a possible biomarker of Parkinson's disease. Neurosci Bull 2014;30(1):134-40.

50. Doty RL. Olfaction in Parkinson's disease and related disorders. Neurobiol Dis 2012;46(3):527-52.

51. Frank RA, Gesteland RC, Bailie J, Rybalsky K, Seiden A, Dulay MF. Characterization of the sniff magnitude test. Arch Otolaryngol Head Neck Surg 2006;132(5):532-6.

52. Reden J, Draf C, Frank RA, Hummel T. Comparison of clinical tests of olfactory function. Eur Arch Otorhinolaryngol 2016;273(4):927-31.

53. Ma LY, Liu GL, Wang DX, Zhang MM, Kou WY, Feng T. Alpha-Synuclein in Peripheral Tissues in Parkinson's Disease. ACS Chem Neurosci 2019;10(2):812-23.

54. Schneider SA, Boettner M, Alexoudi A, Zorenkov D, Deuschl G, Wedel T. Can we use peripheral tissue biopsies to diagnose Parkinson's disease? A review of the literature. Eur J Neurol 2016;23(2):247-61.

55. Witt M, Bormann K, Gudziol V, Pehlke K, Barth K, Minovi A, Hahner A, Reichmann $\mathrm{H}$, Hummel T. Biopsies of olfactory epithelium in patients with Parkinson's disease. Mov Disord 2009;24(6):906-14.

56. Rombaux $\mathrm{P}$, Duprez T, Hummel T. Olfactory bulb volume in the clinical assessment of olfactory dysfunction. Rhinology 2009;47(1):3-9.

57. Buschuter D, Smitka M, Puschmann S, Gerber JC, Witt M, Abolmaal ND, Hummel T. Correlation between olfactory bulb volume and olfactory function. Neuroimage 2008;42(2):498-502.

58. Mueller A, Rodewald A, Reden J, Gerber J, von Kummer R, Humme T. Reduced olfactory bulb volume in post-traumatic and post-infectious olfactory dysfunction. Neuroreport 2005;16(5):475-8.

59. Haehner A, Rodewald A, Gerber JC, Hummel T. Correlation of olfactory function with changes in the volume of the human olfactory bulb. Arch Otolaryngol Head Neck Surg 2008;134(6):621-4

60. Li J, Gu CZ, Su JB, Zhu LH, Zhou Y, Huang HY, Liu CF. Changes in Olfactory Bulb Volume in Parkinson's Disease: A Systematic Review and Meta-Analysis. PLoS One 2016;11(2):e0149286.

61. Brodoehl S, Klingner C, Volk GF, Bitter T, Witte OW, Redecker C. Decreased olfactory bulb volume in idiopathic Parkinson's disease detected by 3.0-tesla magnetic resonance imaging. Mov Disord 2012;27(8):1019-25.

62. Wang J, You H, Liu JF, Ni DF, Zhang ZX, Guan J. Association of olfactory bulb volume and olfactory sulcus depth with olfactory function in patients with Parkinson disease. Am J Neuroradiol 2011;32(4):67781.

63. Paschen L, Schmidt N, Wolff S, Cnyrim C, van Eimeren T, Zeuner KE, Deuschl G, Witt K. The olfactory bulb volume in patients with idiopathic Parkinson's disease. Eur J Neurol 2015;22(7):1068-73.

64. Mueller A, Abolmaali ND, Hakimi AR, Gloeckler T, Herting B, Reichmann $\mathrm{H}$, Hummel T. Olfactory bulb volumes in patients with idiopathic Parkinson's disease a pilot study. J Neural Transm (Vienna) 2005;112(10):1363-70

65. Hakyemez HA, Veyseller B, Ozer F, Ozben S, Bayraktar GI, Gurbuz D Cetin S, Yildirim YS. Relationship of olfactory function with olfactory bulbus volume, disease duration and Unified Parkinson's disease rating scale scores in patients with early stage of idiopathic Parkinson's disease. J Clin Neurosci 2013;20(10):1469-70.

66. Liepelt-Scarfone I, Pilotto A, Muller K, Bormann C, Gauss K, Wurster I, Streffer J, Berg D. Autonomic dysfunction in subjects at high risk for Parkinson's disease. J Neurol 2015;262(12):2643-52.

67. Mendoza-Velasquez JJ, Flores-Vazquez JF, Barron-Velazquez E, SosaOrtiz AL, Illigens BW, Siepmann T. Autonomic Dysfunction in alphaSynucleinopathies. Front Neurol 2019;10:363.

68. Palma JA, Kaufmann H. Autonomic disorders predicting Parkinson's disease. Parkinsonism Relat Disord 2014;20 Suppl 1:S94-8.

69. Matthews PM, Jezzard P. Functional magnetic resonance imaging. J Neurol Neurosurg Psychiatry 2004;75(1):6-12.

70. Abbott RD, Petrovitch H, White LR, Masaki KH, Tanner CM, Curb JD, Grandinetti A, Blanchette PL, Popper JS, Ross GW. Frequency of bowel movements and the future risk of Parkinson's disease. Neurology 2001;57(3):456-62.

71. Gao X, Chen H, Schwarzschild MA, Glasser DB, Logroscino G, Rimm $E B$, Ascherio A. Erectile function and risk of Parkinson's disease. Am J Epidemiol 2007;166(12):1446-50.

72. Savica R, Carlin JM, Grossardt BR, Bower JH, Ahlskog JE, Maraganore $D M$, Bharucha $A E$, Rocca WA. Medical records documentation of constipation preceding Parkinson disease A case-control study. Neurology 2009;73(21):1752-8.
73. Postuma RB, Gagnon JF, Pelletier A, Montplaisir J. Prodromal autonomic symptoms and signs in Parkinson's disease and dementia with Lewy bodies. Mov Disord 2013;28(5):597-604.

74. Adams-Carr KL, Bestwick JP, Shribman S, Lees A, Schrag A, Noyce AJ. Constipation preceding Parkinson's disease: a systematic review and meta-analysis. J Neurol Neurosurg Psychiatry 2016;87(7):710-6.

75. Schrag A, Horsfall L, Walters K, Noyce A, Petersen I. Prediagnostic presentations of Parkinson's disease in primary care: a case-control study. Lancet Neurol 2015;14(1):57-64.

76. Evatt ML, Chaudhuri KR, Chou KL, Cubo E, Hinson V, Kompoliti K Yang CW, Poewe W, Rascol O, Sampaio C, Stebbins GT, Goetz CG. Dysautonomia Rating Scales in Parkinson's Disease: Sialorrhea, Dysphagia, and Constipation-Critique and Recommendations by Movement Disorders Task Force on Rating Scales for Parkinson's Disease. Mov Disord 2009;24(5):635-46.

77. Visser M, Marinus J, Stiggelbout AM, Van Hilten JJ. Assessment of autonomic dysfunction in Parkinson's disease: the SCOPA-AUT. Mov Disord 2004;19(11):1306-12.

78. Knudsen K, Haase AM, Fedorova TD, Bekker AC, Ostergaard K, Krogh K, Borghammer P. Gastrointestinal Transit Time in Parkinson's Disease Using a Magnetic Tracking System. J Parkinsons Dis 2017;7(3):471-9.

79. Sakakibara R, Odaka T, Uchiyama T, Asahina M, Yamaguchi K, Yamaguchi T, Yamanishi T, Hattori T. Colonic transit time and rectoanal videomanometry in Parkinson's disease. J Neurol Neurosurg Psychiatry 2003;74(2):268-72.

80. Knudsen K, Fedorova TD, Bekker AC, Iversen P, Ostergaard K, Krogh K, Borghammer P. Objective Colonic Dysfunction is Far more Prevalent than Subjective Constipation in Parkinson's Disease: A Colon Transit and Volume Study. J Parkinsons Dis 2017;7(2):359-67.

81. De Pablo-Fernandez E, Passananti V, Zarate-Lopez N, Emmanue A, Warner T. Colonic transit, high-resolution anorectal manometry and MRI defecography study of constipation in Parkinson's disease. Parkinsonism Relat Disord 2019;66:195-201.

82. Knudsen K, Borghammer P. Imaging the Autonomic Nervous System in Parkinson's Disease. Curr Neurol Neurosci Rep 2018;18(11):79.

83. Abrahamsson $\mathrm{H}$, Antov S, Bosaeus I. Gastrointestinal and colonic segmental transit time evaluated by a single abdominal $x$-ray in healthy subjects and constipated patients. Scand J Gastroenterol Suppl 1988;152:72-80.

84. Knudsen K, Krogh K, Ostergaard K, Borghammer P. Constipation in Parkinson's Disease: Subjective Symptoms, Objective Markers, and New Perspectives. Mov Disord 2017;32(1):94-105.

85. Durcan R, Wiblin L, Lawson RA, Khoo TK, Yarnall AJ, Duncan GW Brooks DJ, Pavese N, Burn DJ, Grp I-PS. Prevalence and duration of non-motor symptoms in prodromal Parkinson's disease. Eur J Neurol 2019;26(7):979-85.

86. Zhao SK, Wang JM, Xie Q, Luo LM, Zhu ZG, Liu YZ, Luo JT, Zhao ZG. Parkinson's Disease Is Associated with Risk of Sexual Dysfunction in Men but Not in Women: A Systematic Review and Meta-Analysis. J Sex Med 2019;16(3):434-46.

87. Varanda S, Ribeiro da Silva J, Costa AS, Amorim de Carvalho C, Alves JN, Rodrigues M, Carneiro G. Sexual dysfunction in women with Parkinson's disease. Mov Disord 2016;31(11):1685-93.

88. Selvin $E$, Burnett AL, Platz EA. Prevalence and risk factors for erectile dysfunction in the US. Am J Med 2007;120(2):151-7.

89. Pascual-Regueiro N, Baleriola-Julvez JM, Hortelano-Perales M Panach-Navarrete J, Casco-Sales L, Martinez-Jabaloyas JM. Erectile dysfunction: Prevalence and its relationship with lower urinary tract symptoms. Med Clin (Barc) 2020.

90. Rosen RC, Riley A, Wagner G, Osterloh IH, Kirkpatrick J, Mishra A. The international index of erectile function (IIEF): a multidimensional scale for assessment of erectile dysfunction. Urology 1997:49(6):82230.

91. Shalash A, Hamid E, Elrassas H, Abushouk Al, Salem HH. Sexual dysfunction in male patients with Parkinson's disease: related factors and impact on quality of life. Neurol Sci 2020.

92. Bernard BA, Metman LV, Levine L, Ouyang B, Leurgans S, Goetz CG. Sildenafil in the Treatment of Erectile Dysfunction in Parkinson's Disease. Mov Disord Clin Pract 2017;4(3):412-5.

93. McGahuey CA, Gelenberg AJ, Laukes CA, Moreno FA, Delgado $\mathrm{PL}$, McKnight KM, Manber R. The Arizona Sexual Experience Scale (ASEX): reliability and validity. J Sex Marital Ther 2000;26(1):25-40.

94. Elnazer HY, Baldwin DS. Structured review of the use of the Arizona sexual experiences scale in clinical settings. Hum Psychopharmacol 2020;35(3):e2730 
95. Rosen R, Brown C, Heiman J, Leiblum S, Meston C, Shabsigh R, Ferguson D, D'Agostino R, Jr. The Female Sexual Function Index (FSFI): a multidimensional self-report instrument for the assessment of female sexual function. J Sex Marital Ther 2000;26(2):191-208.

96. Sakakibara R, Tateno F, Yamamoto T, Uchiyama T, Yamanishi T. Urological dysfunction in synucleinopathies: epidemiology, pathophysiology and management. Clin Auton Res 2018;28(1):83-101.

97. Sakakibara R, Shinotoh H, Uchiyama T, Sakuma M, Kashiwado M, Yoshiyama M, Hattori T. Questionnaire-based assessment of pelvic organ dysfunction in Parkinson's disease. Auton Neurosci 2001;92(1-2):76-85.

98. Barry MJ, Fowler FJ, Jr., O'Leary MP, Bruskewitz RC, Holtgrewe HL, Mebust WK, Cockett AT. The American Urological Association symptom index for benign prostatic hyperplasia. The Measurement Committee of the American Urological Association. J Urol 1992;148(5):1549-57; discussion 64.

99. Araki I, Kuno S. Assessment of voiding dysfunction in Parkinson's disease by the international prostate symptom score. J Neuro Neurosurg Psychiatry 2000;68(4):429-33.

100. Uebersax JS, Wyman JF, Shumaker SA, McClish DK, Fantl JA. Short forms to assess life quality and symptom distress for urinary incontinence in women: the Incontinence Impact Questionnaire and the Urogenital Distress Inventory. Continence Program for Women Research Group. Neurourol Urodyn 1995;14(2):131-9.

101. Iacovelli E, Gilio F, Meco G, Fattapposta F, Vanacore N, Brusa L, Giacomelli E, Gabriele M, Rubino A, Locuratolo N, lani C, Pichiorri F Colosimo C, Carbone A, Palleschi G, Inghilleri M. Bladder Symptoms Assessed with Overactive Bladder Questionnaire in Parkinson's Disease. Mov Disord 2010;25(9):1203-9.

102. Coyne K, Revicki D, Hunt T, Corey R, Stewart W, Bentkover J, Kurth H, Abrams P. Psychometric validation of an overactive bladder symptom and health-related quality of life questionnaire: The OAB-q Qual Life Res 2002;11(6):563-74.

103. Uchiyama T, Sakakibara R, Yamamoto T, Ito T, Yamaguchi C, Awa Y, Yanagisawa M, Higuchi Y, Sato Y, Ichikawa T, Yamanishi T, Hattori T, Kuwabara S. Urinary dysfunction in early and untreated Parkinson's disease. J Neurol Neurosurg Psychiatry 2011;82(12):1382-6.

104. Freeman R, Wieling W, Axelrod FB, Benditt DG, Benarroch E, Biaggioni I, Cheshire WP, Chelimsky T, Cortelli P, Gibbons $\mathrm{CH}_{\text {, }}$ Goldstein DS, Hainsworth R, Hilz MJ, Jacob G, Kaufmann H, Jordan J, Lipsitz LA, Levine BD, Low PA, Mathias C, Raj SR, Robertson $D$, Sandroni P, Schatz I, Schondorff R, Stewart JM, van Dijk JG. Consensus statement on the definition of orthostatic hypotension, neurally mediated syncope and the postural tachycardia syndrome. Clin Auton Res 2011;21(2):69-72.

105. Goldstein DS. Orthostatic hypotension as an early finding in Parkinson's disease. Clin Auton Res 2006;16(1):46-54.

106. Postuma RB, Gagnon JF, Pelletier A, Montplaisir J. Prodromal autonomic symptoms and signs in Parkinson's disease and dementia with Lewy bodies. Mov Disord 2013;28(5):597-604.

107. Pavy-Le Traon A, Amarenco G, Duerr S, Kaufmann H, Lahrmann $\mathrm{H}_{\text {, }}$ Shaftman SR, Tison F, Wenning GK, Goetz CG, Poewe W, Sampaio C, Schrag A, Stebbins GT, Rascol O. The Movement Disorders task force review of dysautonomia rating scales in Parkinson's disease with regard to symptoms of orthostatic hypotension. Mov Disord 2011;26(11):1985-92.

108. Suarez GA, Opfer-Gehrking TL, Offord KP, Atkinson EJ, O'Brien PC, Low PA. The Autonomic Symptom Profile: a new instrument to assess autonomic symptoms. Neurology 1999;52(3):523-8.

109. Merola A, Romagnolo A, Rosso M, Lopez-Castellanos JR, Wissel BD, Larkin S, Bernardini A, Zibetti M, Maule S, Lopiano L, Espay AJ. Orthostatic hypotension in Parkinson's disease: Does it matter if asymptomatic? Parkinsonism Relat Disord 2016;33:65-71.

110. Hommel ALAJ, Faber MJ, Weerkamp NJ, van Dijk JG, Bloem BR, Koopmans RT. Prevalence and Prescribed Treatments of Orthostatic Hypotension in Institutionalized Patients with Parkinson's Disease. J Parkinsons Dis 2016;6(4):805-10.

111. Schrezenmaier C, Gehrking JA, Hines SM, Low PA, Benrud-Larson LM, Sandroni P. Evaluation of orthostatic hypotension: Relationship of a new self-report instrument to laboratory-based measures. Mayo Clinic Proceedings 2005;80(3):330-4.

112. Kim HA, Lee H, Park KJ, Lim JG. Autonomic dysfunction in patients with orthostatic dizziness: Validation of orthostatic grading scale and comparison of Valsalva maneuver and head-up tilt testing results. J Neurol Sci 2013;325(1-2):61-6.

113. Shibao C, Lipsitz LA, Biaggioni I, American Society of Hypertension Writing $\mathrm{G}$. Evaluation and treatment of orthostatic hypotension. J Am Soc Hypertens 2013;7(4):317-24.

114. Lahrmann H, Cortelli P, Hilz M, Mathias CJ, Struhal W, Tassinari M. EFNS guidelines on the diagnosis and management of orthostatic hypotension. Eur J Neurol 2006;13(9):930-6.

115. Shaw BH, Garland EM, Black BK, Paranjape SY, Shibao CA, Okamoto LE, Gamboa A, Diedrich A, Plummer WD, Dupont WD, Biaggioni I, Robertson D, Raj SR. Optimal diagnostic thresholds for diagnosis of orthostatic hypotension with a 'sit-to-stand test'. J Hypertens 2017;35(5):1019-25

116. Gibbons $\mathrm{CH}$, Schmidt $\mathrm{P}$, Biaggioni I, Frazier-Mills $C$, Freeman $\mathrm{R}$ Isaacson S, Karabin B, Kuritzky L, Lew M, Low P, Mehdirad A, Raj $\mathrm{SR}$, Vernino $\mathrm{S}$, Kaufmann $\mathrm{H}$. The recommendations of a consensus panel for the screening, diagnosis, and treatment of neurogenic orthostatic hypotension and associated supine hypertension. $J$ Neurol 2017;264(8):1567-82.

117. Postuma RB, Iranzo A, Hogl B, Arnulf I, Ferini-Strambi L, Manni R, Miyamoto T, Oertel W, Dauvilliers Y, Ju YE, Puligheddu M, Sonka K, Pelletier A, Santamaria J, Frauscher B, Leu-Semenescu S, Zucconi M, Terzaghi M, Miyamoto M, Unger MM, Carlander B, Fantini ML, Montplaisir JY. Risk factors for neurodegeneration in idiopathic rapid eye movement sleep behavior disorder: a multicenter study. Ann Neurol 2015;77(5):830-9.

118. Iranzo A, Fernandez-Arcos A, Tolosa E, Serradell M, Molinuevo JL, Valldeoriola F, Gelpi E, Vilaseca I, Sanchez-Valle R, Llado A, Gaig C, Santamaria J. Neurodegenerative disorder risk in idiopathic REM sleep behavior disorder: study in 174 patients. PLoS One 2014;9(2):e89741.

119. Schenck CH, Boeve BF, Mahowald MW. Delayed emergence of a parkinsonian disorder or dementia in $81 \%$ of older men initially diagnosed with idiopathic rapid eye movement sleep behavior disorder: a 16-year update on a previously reported series. Sleep Med 2013;14(8):744-8.

120. Sateia MJ. International Classification of Sleep Disorders-Third Edition Highlights and Modifications. Chest 2014;146(5):1387-94.

121. Nomura T, Inoue Y, Kagimura T, Uemura Y, Nakashima K. Utility of the REM sleep behavior disorder screening questionnaire (RBDSQ) in Parkinson's disease patients. Sleep Med 2011;12(7):711-3.

122. Stiasny-Kolster K, Mayer G, Schafer S, Moller JC, HeinzelGutenbrunner M, Oertel WH. The REM sleep behavior disorder screening questionnaire--a new diagnostic instrument. Mov Disord 2007;22(16):2386-93

123. Buskova J, Perinova P, Miletinova E, Dusek P, Ruzicka E, Sonka K, Kemlink D. Validation of the REM sleep behavior disorder screening questionnaire in the Czech population. BMC Neurol 2019;19(1):110.

124. Nomura $T$, Inoue $Y$, Kagimura $T$, Kusumi $M$, Nakashima K. Validity of the Japanese version of the REM Sleep Behavior Disorder (RBD) Screening Questionnaire for detecting probable RBD in the general population. Psychiatry Clin Neurosci 2015;69(8):477-82.

125. Marelli S, Rancoita PM, Giarrusso F, Galbiati A, Zucconi M, Oldani A, Di Serio C, Ferini-Strambi L. National validation and proposed revision of REM sleep behavior disorder screening questionnaire (RBDSQ). J Neurol 2016;263(12):2470-5.

126. Postuma RB, Arnulf I, Hogl B, Iranzo A, Miyamoto T, Dauvilliers $Y$, Oertel W, Ju YE, Puligheddu M, Jennum P, Pelletier A, Wolfson C, Leu-Semenescu S, Frauscher B, Miyamoto M, Cochen De Cock V, Unger MM, Stiasny-Kolster K, Fantini ML, Montplaisir JY. A singlequestion screen for rapid eye movement sleep behavior disorder: a multicenter validation study. Mov Disord 2012;27(7):913-6.

127. Abbott RD, Ross GW, White LR, Tanner CM, Masaki KH, Nelson JS, Curb JD, Petrovitch H. Excessive daytime sleepiness and subsequent development of Parkinson disease. Neurology 2005;65(9):1442-6.

128. Gao J, Huang X, Park Y, Hollenbeck A, Blair A, Schatzkin A, Chen H. Daytime napping, nighttime sleeping, and Parkinson disease. Am J Epidemiol 2011;173(9):1032-8.

129. Johns MW. A new method for measuring daytime sleepiness: the Epworth sleepiness scale. Sleep 1991;14(6):540-5.

130. Hogl B, Seppi K, Brandauer E, Glatzl S, Frauscher B, Niedermuller U, Wenning G, Poewe W. Increased daytime sleepiness in Parkinson's disease: a questionnaire survey. Mov Disord 2003;18(3):319-23. 
131. Ghorayeb I, Loundou A, Auquier P, Dauvilliers Y, Bioulac B, Tison F. A nationwide survey of excessive daytime sleepiness in Parkinson's disease in France. Mov Disord 2007;22(11):1567-72.

132. Kumar S, Bhatia M, Behari M. Excessive daytime sleepiness in Parkinson's disease as assessed by Epworth Sleepiness Scale (ESS). Sleep Medicine 2003;4(4):339-42.

133. Zea-Sevilla MA, Martinez-Martin P. Rating scales and questionnaires for assessment of sleep disorders in Parkinson's disease: what they inform about? J Neural Transm (Vienna) 2014;121 Suppl 1:S33-40.

134. Chaudhuri KR, Pal S, DiMarco A, Whately-Smith C, Bridgman K, Mathew R, Pezzela FR, Forbes A, Hogl B, Trenkwalder C. The Parkinson's disease sleep scale: a new instrument for assessing sleep and nocturnal disability in Parkinson's disease. J Neurol Neurosurg Psychiatry 2002;73(6):629-35.

135. Trenkwalder C, Kohnen R, Hogl B, Metta V, Sixel-Doring F, Frauscher B, Hulsmann J, Martinez-Martin P, Chaudhuri KR. Parkinson's disease sleep scale--validation of the revised version PDSS-2. Mov Disord 2011;26(4):644-52.

136. Marinus J, Visser M, van Hilten JJ, Lammers GJ, Stiggelbout AM Assessment of sleep and sleepiness in Parkinson disease. Sleep 2003;26(8):1049-54.

137. Goetz CG, Tilley BC, Shaftman SR, Stebbins GT, Fahn S, MartinezMartin P, Poewe W, Sampaio C, Stern MB, Dodel R, Dubois B, Holloway R, Jankovic J, Kulisevsky J, Lang AE, Lees A, Leurgans S, LeWitt PA, Nyenhuis D, Olanow CW, Rascol O, Schrag A, Teresi JA, Hilten JJ, LaPelle N, UPDRS MDS. Movement Disorder SocietySponsored Revision of the Unified Parkinson's Disease Rating Scale (MDS-UPDRS): Scale Presentation and Clinimetric Testing Results. Mov Disord 2008;23(15):2129-70.

138. Leentjens AF, Van den Akker M, Metsemakers JF, Lousberg $R$, Verhey FR. Higher incidence of depression preceding the onset of Parkinson's disease: a register study. Mov Disord 2003;18(4):414-8.

139. Alonso A, Rodriguez LAG, Logroscino G, Hernan MA. Use of antidepressants and the risk of Parkinson's disease: a prospective study. J Neurol Neurosurg Psychiatry 2009;80(6):671-4.

140. Fang F, Xu Q, Park Y, Huang XM, Hollenbeck A, Blair A, Schatzkin A, Kamel F, Chen HL. Depression and the Subsequent Risk of Parkinson's Disease in the NIH-AARP Diet and Health Study. Mov Disord 2010;25(9):1157-62.

141. Gustafsson H, Nordstrom A, Nordstrom P. Depression and subsequent risk of Parkinson disease: A nationwide cohort study. Neurology 2015;84(24):2422-9.

142. Schrag A, Barone P, Brown RG, Leentjens AFG, McDonald WM Starkstein S, Weintraub D, Poewe W, Rascol O, Sampaio C, Stebbins GT, Goetz CG. Depression rating scales in Parkinson's disease: Critique and recommendations. Mov Disord 2007;22(8):1077-92.

143. Goodarzi Z, Mrklas KJ, Roberts DJ, Jette N, Pringsheim T, HolroydLeduc J. Detecting depression in Parkinson disease: A systematic review and meta-analysis. Neurology 2016;87(4):426-37.

144. Sheikh JI, Yesavage JA. Geriatric Depression Scale (GDS): Recent evidence and development of a shorter version. Clinical Gerontologist: J Aging Health 1986;5(1-2):165-73.

145. Yesavage JA, Brink TL, Rose TL, Lum O, Huang V, Adey M, Leirer VO Development and Validation of a Geriatric Depression Screening Scale - a Preliminary-Report. J Psychiatr Res 1983;17(1):37-49.

146. Beck AT, Ward CH, Mendelson M, Mock J, Erbaugh J. An inventory for measuring depression. Arch Gen Psychiatry 1961;4:561-71.

147. Montgomery SA, Asberg M. A new depression scale designed to be sensitive to change. Br J Psychiatry 1979;134:382-9.

148. Hamilton M. A rating scale for depression. J Neurol Neurosurg Psychiatry 1960;23:56-62.

149. Zigmond AS, Snaith RP. The Hospital Anxiety and Depression Scale. Acta Psychiatr Scand 1983;67(6):361-70.

150. Zung WW. A Self-Rating Depression Scale. Arch Gen Psychiatry 1965;12:63-70.

151. Darweesh SKL, Wolters FJ, Postuma RB, Stricker BH, Hofman A, Koudstaal PJ, Ikram MK, Ikram MA. Association Between Poor Cognitive Functioning and Risk of Incident Parkinsonism The Rotterdam Study. Jama Neurol 2017;74(12):1431-8.

152. Schrag A, Anastasiou Z, Ambler G, Noyce A, Walters K. Predicting diagnosis of Parkinson's disease: A risk algorithm based on primary care presentations. Mov Disord 2019;34(4):480-6.

153. Weintraub D, Chahine LM, Hawkins KA, Siderowf A, Eberly S, Oakes D, Seibyl J, Stern MB, Marek K, Jennings D, Investigators P. Cognition and the course of prodromal Parkinson's disease. Mov Disord 2017;32(11):1640-5.

154. Fengler S, Liepelt-Scarfone I, Brockmann K, Schaffer E, Berg D, Kalbe E. Cognitive Changes in Prodromal Parkinson's Disease: A Review. Mov Disord 2017;32(12):1655-66.

155. Skorvanek M, Goldman JG, Jahanshahi M, Marras C, Rektorova I, Schmand B, van Duijn E, Goetz CG, Weintraub D, Stebbins GT, Martinez-Martin P, members of the MDSRSRC. Global scales for cognitive screening in Parkinson's disease: Critique and recommendations. Mov Disord 2018;33(2):208-18.

156. Mattis S. Dementia rating scale: DRS: Professional manual. PAR 1988.

157. Nasreddine ZS, Phillips NA, Bedirian V, Charbonneau S, Whitehead V, Collin I, Cummings JL, Chertkow H. The Montreal Cognitive Assessment, MoCA: a brief screening tool for mild cognitive impairment. J Am Geriatr Soc 2005;53(4):695-9.

158. Pagonabarraga J, Kulisevsky J, Llebaria G, Garcia-Sanchez C, Pascual-Sedano B, Gironell A. Parkinson's disease-cognitive rating scale: a new cognitive scale specific for Parkinson's disease. Mov Disord 2008;23(7):998-1005.

159. Folstein MF, Folstein SE, McHugh PR. "Mini-mental state". A practical method for grading the cognitive state of patients for the clinician. J Psychiatr Res 1975;12(3):189-98.

160. Blanchet PJ, Brefel-Courbon C. Chronic pain and pain processing in Parkinson's disease. Prog Neuropsychopharmacol Biol Psychiatry 2018;87(Pt B):200-6.

161. Farnikova K, Krobot A, Kanovsky P. Musculoskeletal problems as an initial manifestation of Parkinson's disease: a retrospective study. J Neurol Sci 2012;319(1-2):102-4.

162. O'Sullivan SS, Williams DR, Gallagher DA, Massey LA, SilveiraMoriyama L, Lees AJ. Nonmotor symptoms as presenting complaints in Parkinson's disease: A clinicopathological study. Mov Disord 2008;23(1):101-6.

163. Pont-Sunyer C, Hotter A, Gaig C, Seppi K, Compta Y, Katzenschlager R, Mas N, Hofeneder D, Brucke T, Bayes A, Wenzel K, Infante J, Zach H, Pirker W, Posada IJ, Alvarez R, Ispierto L, De Fabregues O, Callen A, Palasi A, Aguilar M, Marti MJ, Valldeoriola F, Salamero M, Poewe W, Tolosa E. The Onset of Nonmotor Symptoms in Parkinson's Disease (The ONSET PD Study). Mov Disord 2015;30(2):229-37.

164. Perez-Lloret S, de Andrade DC, Lyons KE, Rodriguez-Blazquez C, Chaudhuri KR, Deuschl G, Cruccu G, Sampaio C, Goetz CG, Schrag A, Martinez-Martin P, Stebbins G, Dev MCRS. Rating Scales for Pain in Parkinson's Disease: Critique and Recommendations. Mov Disord Clin Pract 2016;3(6):527-37.

165. Chaudhuri KR, Rizos A, Trenkwalder C, Rascol O, Pal S, Martino D, Carroll C, Paviour D, Falup-Pecurariu C, Kessel B, Silverdale M, Todorova A, Sauerbier A, Odin P, Antonini A, Martinez-Martin P, EUROPAR, Grp INMPS. King's Parkinson's disease pain scale, the first scale for pain in PD: An international validation. Mov Disord 2015;30(12):1623-31.

166. Bouhassira D, Attal N, Alchaar H, Boureau F, Brochet B, Bruxelle J, Cunin G, Fermanian J, Ginies P, Grun-Overdyking A, Jafari-Schluep H, Lanteri-Minet M, Laurent B, Mick G, Serrie A, Valade D, Vicaut E. Comparison of pain syndromes associated with nervous or somatic lesions and development of a new neuropathic pain diagnostic questionnaire (DN4). Pain 2005;114(1-2):29-36.

167. Grambalova Z, Kaiserova M, Vastik M, Mensikova K, Otruba P, Zapletalova J, Dufek J, Kanovsky P. Peripheral neuropathy in Parkinson's disease. Neuro Endocrinol Lett 2015;36(4):363-7.

168. Paul DA, Qureshi ARM, Rana AQ. Peripheral neuropathy in Parkinson's disease. Neurol Sci 2020;41(10):2691-701.

169. Podgorny PJ, Suchowersky O, Romanchuk KG, Feasby TE. Evidence for small fiber neuropathy in early Parkinson's disease. Parkinsonism Relat Disord 2016;28:94-9.

170. Farnikova K, Kanovsky P, Nestrasil I, Otruba P. Coexistence of parkinsonism, dementia and upper motor neuron syndrome in four Czech patients. J Neurol Sci 2010;296(1-2):47-54.

171. Uitti RJ, Berry K, Yasuhara O, Eisen A, Feldman H, McGeer PL, Calne DB. Neurodegenerative 'overlap' syndrome: Clinical and pathological features of Parkinson's disease, motor neuron disease, and Alzheimer's disease. Parkinsonism Relat Disord 1995;1(1):21-34.

172. Calzetti S, Bellanova MF, Negrotti A, Saccani E, Capozzi A, Pietrini V. Non-length-dependent somatosensory small fiber pathology presenting with restless legs syndrome in pre-motor Parkinson's disease. Evidence from skin biopsy in four patients. J Clin Neurosci 2019;69: 39-42. 
173. Terkelsen AJ, Karlsson P, Lauria G, Freeman R, Finnerup NB, Jensen TS. The diagnostic challenge of small fibre neuropathy: clinical presentations, evaluations, and causes. Lancet Neurology 2017;16(11):934-44.

174. Barber TR, Klein JC, Mackay CE, Hu MTM. Neuroimaging in premotor Parkinson's disease. Neuroimage Clin 2017;15:215-27.

175. Brooks DJ. Molecular imaging of dopamine transporters. Ageing Res Rev 2016;30:114-21.

176. Abbasi Gharibkandi N, Hosseinimehr SJ. Radiotracers for imaging of Parkinson's disease. Eur J Med Chem 2019;166:75-89.

177. Li DH, He YC, Liu J, Chen SD. Diagnostic Accuracy of Transcranial Sonography of the Substantia Nigra in Parkinson's disease: A Systematic Review and Meta-analysis. Scientific Reports 2016;6.

178. Tao AY, Chen GZ, Deng YB, Xu RF. Accuracy of Transcrania Sonography of the Substantia Nigra for Detection of Parkinson's Disease: A Systematic Review and Meta-Analysis. Ultrasound Med Biol 2019;45(3):628-41.

179. Garcia-Lorenzo D, Longo-Dos Santos C, Ewenczyk C, LeuSemenescu S, Gallea C, Quattrocchi G, Pita Lobo P, Poupon C, Benali H, Arnulf I, Vidailhet M, Lehericy S. The coeruleus/subcoeruleus complex in rapid eye movement sleep behaviour disorders in Parkinson's disease. Brain 2013;136(Pt 7):2120-9.

180. Sulzer D, Cassidy C, Horga G, Kang UJ, Fahn S, Casella L, Pezzoli G, Langley J, Hu XPP, Zucca FA, Isaias IU, Zecca L. Neuromelanin detection by magnetic resonance imaging (MRI) and its promise as a biomarker for Parkinson's disease. Npj Parkinsons Disease 2018;4.

181. Heim B, Krismer F, De Marzi R, Seppi K. Magnetic resonance imaging for the diagnosis of Parkinson's disease. J Neural Transm 2017;124(8):915-64.

182. Filippi M, Elisabetta S, Piramide N, Agosta F. Functional MRI in Idiopathic Parkinson's Disease. Imaging in Movement Disorders: Imaging Methodology and Applications in Parkinson's Disease 2018;141:439-67.

183. Ghadery C, Strafella AP. New Imaging Markers for Movement Disorders. Curr Neurol Neurosci Rep 2018;18(5):22.

184. Rascol O, Schelosky L. 123I-metaiodobenzylguanidine scintigraphy in Parkinson's disease and related disorders. Mov Disord 2009;24 Suppl 2:S732-41.

185. Sakakibara R, Tateno F, Kishi M, Tsuyusaki Y, Terada H, Inaoka T. MIBG myocardial scintigraphy in pre-motor Parkinson's disease: a review. Parkinsonism Relat Disord 2014;20(3):267-73.

186. Sakakibara R, Tateno F, Aiba Y, Ogata T, Kishi M, Terada H, Inaoka T, Nakatsuka T, Matsuoka K. MIBG Myocardial Scintigraphy Identifies Premotor PD/DLB During a Negative DAT Scan Period: Second Report. Mov Disord Clin Pract 2019;6(1):46-50.

187. Tsukita K, Sakamaki-Tsukita H, Tanaka K, Suenaga T, Takahashi R. Value of in vivo alpha-synuclein deposits in Parkinson's disease: A systematic review and meta-analysis. Mov Disord 2019;34(10):145263.

188. Malek N, Swallow D, Grosset KA, Anichtchik O, Spillantini M, Grosset DG. Alpha-synuclein in peripheral tissues and body fluids as a biomarker for Parkinson's disease - a systematic review. Acta Neurol Scand 2014;130(2):59-72.

189. Vilas D, Iranzo A, Tolosa E, Aldecoa I, Berenguer J, Vilaseca I, Mart C, Serradell M, Lomena F, Alos L, Gaig C, Santamaria J, Gelpi E. Assessment of alpha-synuclein in submandibular glands of patients with idiopathic rapid-eye-movement sleep behaviour disorder: a case-control study. Lancet Neurology 2016;15(7):708-18.

190. Chung SJ, Kim J, Lee HJ, Ryu HS, Kim K, Lee JH, Jung KW, Kim MJ, Kim MJ, Kim YJ, Yun SC, Lee JY, Hong SM, Myung SJ. Alpha-synuclein in gastric and colonic mucosa in Parkinson's disease: Limited role as a biomarker. Mov Disord 2016;31(2):241-9.

191. Andersen AD, Binzer M, Stenager E, Gramsbergen JB. Cerebrospinal fluid biomarkers for Parkinson's disease - a systematic review. Acta Neurol Scand 2017;135(1):34-56.
192. Jimenez-Jimenez FJ, Alonso-Navarro H, Garcia-Martin E, Agundez JA. Cerebrospinal fluid biochemical studies in patients with Parkinson's disease: toward a potential search for biomarkers for this disease. Front Cell Neurosci 2014;8:369.

193. Goldstein DS, Holmes C, Lopez GJ, Wu T, Sharabi Y. Cerebrospinal fluid biomarkers of central dopamine deficiency predict Parkinson's disease. Parkinsonism Relat Disord 2018;50:108-12.

194. Zhang J, Sokal I, Peskind ER, Quinn JF, Jankovic J, Kenney C, Chung KA, Millard SP, Nutt JG, Montine TJ. CSF multianalyte profile distinguishes Alzheimer and Parkinson diseases. Am J Clin Pathol 2008;129(4):526-9.

195. Yu SY, Zuo LJ, Wang F, Chen ZJ, Hu Y, Wang YJ, Wang XM, Zhang W. Potential biomarkers relating pathological proteins, neuroinflammatory factors and free radicals in PD patients with cognitive impairment: a cross-sectional study. BMC Neurol 2014;14:113.

196. Majbour NK, Aasly JO, Hustad E, Thomas MA, Vaikath NN, Elkum N, van de Berg WDJ, Tokuda T, Mollenhauer B, Berendse HW, El-Agnaf OMA. CSF total and oligomeric alpha-Synuclein along with TNFalpha as risk biomarkers for Parkinson's disease: a study in LRRK2 mutation carriers. Transl Neurodegener 2020;9(1):15.

197. Kalia LV. Diagnostic biomarkers for Parkinson's disease: focus on a-synuclein in cerebrospinal fluid. Parkinsonism Relat Disord 2019;59:21-5.

198. Compta Y, Valente T, Saura J, Segura B, Iranzo A, Serradell M, Junque $C$, Tolosa E, Valldeoriola F, Munoz E, Santamaria J, Camara A, Fernandez M, Fortea J, Buongiorno M, Molinuevo JL, Bargallo N, Marti MJ. Correlates of cerebrospinal fluid levels of oligomeric- and total-alpha-synuclein in premotor, motor and dementia stages of Parkinson's disease. J Neurol 2015;262(2):294-306.

199. Prikrylova Vranova H, Mares J, Nevrly M, Stejskal D, Zapletalova J, Hlustik P, Kanovsky P. CSF markers of neurodegeneration in Parkinson's disease. J Neural Transm (Vienna) 2010;117(10):1177-81.

200. Hall S, Ohrfelt A, Constantinescu R, Andreasson U, Surova Y, Bostrom F, Nilsson C, Hakan W, Decraemer H, Nagga K, Minthon L, Londos E, Vanmechelen E, Holmberg B, Zetterberg H, Blennow K, Hansson O. Accuracy of a panel of 5 cerebrospinal fluid biomarkers in the differential diagnosis of patients with dementia and/or parkinsonian disorders. Arch Neurol 2012;69(11):1445-52.

201. Alves G, Bronnick K, Aarsland D, Blennow K, Zetterberg H, Ballard C, Kurz MW, Andreasson U, Tysnes OB, Larsen JP, Mulugeta E. CSF amyloid-beta and tau proteins, and cognitive performance, in early and untreated Parkinson's disease: the Norwegian ParkWest study. J Neurol Neurosurg Psychiatry 2010;81(10):1080-6.

202. Magdalinou NK, Paterson RW, Schott JM, Fox NC, Mummery C, Blennow K, Bhatia K, Morris HR, Giunti P, Warner TT, de Silva R, Lees AJ, Zetterberg $\mathrm{H}$. A panel of nine cerebrospinal fluid biomarkers may identify patients with atypical parkinsonian syndromes. $J$ Neurol Neurosurg Psychiatry 2015;86(11):1240-7.

203. Vranova HP, Henykova E, Kaiserova M, Mensikova K, Vastik M, Mares J, Hlustik P, Zapletalova J, Strnad M, Stejskal D, Kanovsky P. Tau protein, beta-amyloid(1)(-)(4)(2) and clusterin CSF levels in the differential diagnosis of Parkinsonian syndrome with dementia. J Neurol Sci 2014;343(1-2):120-4.

204. Prikrylova Vranova H, Henykova E, Mares J, Kaiserova M, Mensikova K, Vastik M, Hlustik P, Zapletalova J, Strnad M, Stejskal D, Kanovsky P. Clusterin CSF levels in differential diagnosis of neurodegenerative disorders. J Neurol Sci 2016;361:117-21.

205. Maarouf CL, Beach TG, Adler CH, Shill HA, Sabbagh MN, Wu T, Walker DG, Kokjohn TA, Roher AE, Arizona PDC. Cerebrospinal fluid biomarkers of neuropathologically diagnosed Parkinson's disease subjects. Neurol Res 2012;34(7):669-76.

206. Olsson B, Constantinescu R, Holmberg B, Andreasen N, Blennow K, Zetterberg $\mathrm{H}$. The glial marker $\mathrm{YKL}-40$ is decreased in synucleinopathies. Mov Disord 2013;28(13):1882-5. 